\title{
Potentials of some entomopathogens against the brown marmorated stink bug, Halyomorpha halys (Stål, 1855) (Hemiptera: Pentatomidae)
}

\author{
Elif Tozlu', Islam Saruhan², Göksel Tozlu ${ }^{1 *}$ D, Recep Kotan ${ }^{1}$, Fatih Dadaşoğlu ${ }^{1}$ and Nasibe Tekiner ${ }^{1}$
}

\begin{abstract}
The brown marmorated stink bug, Halyomorpha halys (Stål, 1855) (Hemiptera: Pentatomidae), is an invasive harmful pest species due to its economic losses. Its wide host range and continuous movement make its control difficult with insecticides. Biological control has recently gained importance due to the negative aspects of chemical control. The study evaluated the biological control tools by testing the entomopathogens against the pest by 11 bacteria strains and 1 fungal isolate. Brevibacillus, Bacillus, Pantoea, Vibrio, Pseudomonas, and Beauveria were tested against the nymphs of $\mathrm{H}$. halys under controlled conditions. All applied entomopathogens had potentials for controlling $\mathrm{H}$. halys. Mortality rates of 75 and $100 \%$ were obtained by the bacteria strains and $76.19 \%$ by the fungus, B. bassiana. Successfully reaching a 100\% control rate, the bacterial isolates of the Bacillus cereus GC subgroup B and Pantoea agglomerans GC subgroup were recorded to have a greater potential than the others.
\end{abstract}

Keywords: Halyomorpha halys, Entomopathogens, Biological control, Potentials

\section{Background}

The brown marmorated stink bug, Halyomorpha halys (Stål, 1855) (Hemiptera: Pentatomidae) is a polyphagous pest that has more than 300 host plants. It is originated from East Asia (Rider 2006). It was identified as a new invasive species in the USA in 2001 (Hoebeke and Carter, 2003) and then widely populated in several countries worldwide (Haye et al. 2015). H. halys was first detected in Turkey by Çerçi and Koçak (2017) in Istanbul. Göktürk and Tozlu (2019) reported that they identified the species in 2016 in the coasts of the Black Sea. The damage caused by $H$. halys is known by its feeding on various plant species worldwide including economically important plants (Kuhar et al. 2012 and Rice et al. 2014). The pest is known also spreading certain plant diseases (Bernon et al. 2004).

Chemical control is often the first tactic that farmers or pest managers think of such notorious pest. However,

\footnotetext{
* Correspondence: gtozlu@atauni.edu.tr

${ }^{1}$ Faculty of Agriculture, Department of Plant Protection, Atatürk University, 25240 Erzurum, Turkey

Full list of author information is available at the end of the article
}

its continuous movement by easily flying from field to field makes its control with insecticides difficult (Bariselli et al. 2016). The negative effects of pesticides on the environment and human health have reached vast dimensions and brought along the absolute need to develop alternative control strategies and reduction of the use of pesticides. Biological methods have gained importance in the solution of this problem, and the need to develop biological products that can reduce the negative effects of chemicals on the environment and human health has been emphasized in every platform, leading to the idea to investigate the means of biological control. Many entomopathogens such as Bacillus thuringiensis, Beauveria bassiana, and Metarhizium anisopliae can be mass-produced, formulated, and applied to pest populations in a manner analogous to chemical pesticides, i.e., as non-persistent remedial treatments that are released inundatively (Bhattarai et al. 2016).

This study aimed to evaluate the potentials of some entomopathogens such as $B$. thuringiensis kurstaki, $B a$ cillus atrophaeus, Bacillus sphaericus, Bacillus cereus, Pantoea agglomerans, Pseudomonas flourescens, Vibrio 
hollisae, and Brevibacillus brevis that can be recommended as the biological control of $H$. halys. The study was carried out under laboratory conditions.

\section{Materials and methods Collection of harmful nymphs}

Nymphs of $H$. halys were collected from the hazelnut, corn, and bean in Artvin, Turkey, using sweep net and shaking various parts of the plants on a white bed sheet $\left(3 \times 3.5 \mathrm{~m}^{2}\right)$, while its eggs were collected using visual inspection. The hazelnut leaves with egg packs and nymphs were placed in containers and brought to the Plant Clinical Laboratory of the Plant Protection Department of Atatürk University, Faculty of Agriculture, Turkey.

\section{Entomopathogenic bacterial and fungal isolates}

Entomopathogen strains, previously tested against other pests in other studies, and were available in the Atatürk University, Faculty of Agriculture, Plant Protection Department and kept at $-80^{\circ} \mathrm{C}$ in the Nutrient Broth (NA; Difco) containing $15 \%$ glycerol after culture in the Nutrient Agar (NA; Difco) medium were used. As the entomopathogen fungus, Beauveria bassiana ET 10 fungal isolate that was available in the Mycology Laboratory of the Atatürk University, Faculty of Agriculture, Plant Protection Department and kept in tubes containing Potato Dextrose Agar (PDA; Difco) after isolation the Sphenoptera antiqua (Illiger) larvae, a pest of sainfoin (Onobrychis sativa L. (Fabacea)), was investigated (Table 1).
Identification of entomopathogenic bacteria with MIS

The extraction and analysis of the fatty acid methyl esters of the bacterial biocontrol isolates were carried out, following the standard protocol of the Microbial Identification System (MIS) (MIDI, Inc., Newark, DE) (Paisley 1995). The bacteria strains that were prepared from the fresh cultures, using a sterile platin loop, were analyzed, using the MIS device and the identification results were obtained.

\section{Hypersensitivity to tobacco test of the bacterial biocontrol agents}

The fresh leaves of the tobacco, Nicotina tabacum L. var. Samsun tobacco variety that were grown in pots, were used in the hypersensitivity to tobacco test. The suspensions $\left(10^{8}\right.$ cells $\left./ \mathrm{ml}\right)$ that were prepared, using the bacterial cultures grown in the NA medium for $24-48 \mathrm{~h}$, were injected between 2 adjacent trachea and the leaves were inspected for signs of symptoms. Those that did not show symptoms in tobacco leaves were regarded as negative, while those that show symptoms in tobacco leaves were regarded as positive (Klement, 1964).

\section{Preparation of the bacterial suspensions}

The 3-4-phase inoculation of the tested bacteria into the NA medium was carried out and the strains were cultured for $24 \mathrm{~h}$ at $30{ }^{\circ} \mathrm{C}$ to obtain fresh cultures. A single bacteria colony that was collected from the cultures, using a sterile loop under controlled conditions, was inoculated into the Erlenmeyer flasks containing $300 \mathrm{ml}$ Nutrient Broth (NB) and incubated at $27^{\circ} \mathrm{C}$ for $24 \mathrm{~h}$ in a thermostatic shaker at $250 \mathrm{rpm}$. The bacteria density in

Table 1 Identification and similarity indices of the bacterial strains and fungal isolate used in the study

\begin{tabular}{|c|c|c|c|c|c|c|}
\hline \multicolumn{7}{|c|}{ Bacterial strains } \\
\hline Strain & Isolated from & \multicolumn{2}{|l|}{$\begin{array}{c}\text { MIS } \\
\text { Identification results }\end{array}$} & S & $H R$ & Reference \\
\hline FD 1 & Malacosoma neustria & \multicolumn{2}{|l|}{ Brevibacillus brevis } & 0.625 & - & Tozlu et al. 2011 \\
\hline FD 16 & Yponomeuta evonymella & \multicolumn{2}{|l|}{ Bacillus thuringiensis kurstaki } & 0.805 & - & Dadaşoğlu et al. 2016 \\
\hline FD 17 & Yponomeuta evonymella & \multicolumn{2}{|l|}{ Bacillus atrophaeus } & 0.459 & - & Tozlu et al. 2011 \\
\hline FD 49 & Culex sp. & \multicolumn{2}{|l|}{ Bacillus sphaericus } & 0.681 & - & Dadaşoğlu et al. 2016 \\
\hline FD 51 & Culex sp. & \multicolumn{2}{|l|}{ Bacillus thuringiensis kurstaki } & 0.368 & - & Dadaşoğlu et al. 2016 \\
\hline FD 63 & Yponomeuta evonymella & \multicolumn{2}{|l|}{ Bacillus cereus } & 0.241 & - & Tozlu et al. 2011 \\
\hline FD 68 & Melolontha melolontha & \multicolumn{2}{|l|}{ Pantoea agglomerans } & 0.734 & - & In this study \\
\hline FD 69 & Melolontha melolontha & \multicolumn{2}{|l|}{ Pantoea agglomerans } & 0.552 & - & In this study \\
\hline FD 70 & Melolontha melolontha & \multicolumn{2}{|l|}{ Vibrio hollisae } & 0.476 & - & In this study \\
\hline FD 71 & Melolontha melolontha & \multicolumn{2}{|l|}{ Pseudomonas flourescens } & 0.913 & - & In this study \\
\hline FDP 8 & Bemisia tabaci & \multicolumn{2}{|l|}{ Bacillus cereus } & 0.652 & - & Tozlu et al. 2011 \\
\hline \multicolumn{7}{|c|}{ Fungal isolate } \\
\hline Isolate & Isolated from & ITS Identification Result & $S$ & \multicolumn{2}{|c|}{ ITS 1 sequences } & Reference \\
\hline ET 10 & Sphenoptera antiqua & Beauveria bassiana & 0.99 & \multicolumn{2}{|c|}{ GB |KY806126| } & Tozlu et al. 2017 \\
\hline
\end{tabular}

S Similarity, - negative effect, HR hypersensitivity 
the aqueous culture was adjusted at $\left(1 \times 10^{8} \mathrm{CFU} / \mathrm{ml}\right)$ by a spectrophotometry, using NB medium and transferred to sterile spray bottles.

\section{Preparation of the fungal conidia suspension}

Conidia formation was obtained by the incubation of the B. bassiana ET 10 isolate in the Sabourth Dextrose Agar (SDA) medium at $25{ }^{\circ} \mathrm{C}$ and $80 \% \mathrm{RH}$ for $2-3$ weeks. Then, the surface of the culture was rinsed with $0.2 \mathrm{ml} / \mathrm{l}$ Tween-80 solution (Quesada-Moraga et al. 2006) into sterile water-containing bottles to prepare the stock suspension. The conidia suspension was adjusted at $5.7 \times$ $10^{5}$ conidia/ml using hemocytometry.

\section{Testing the entomopathogens against the pest}

Fresh green beans were placed in each Petri dish $(9 \mathrm{~cm})$, and 6 nymphs (third and fourth nymphal instars) were counted and left in the Petri dishes and then sprayed by the bacteria and fungus suspensions. The entomopathogen-applied Petri dishes were kept under controlled conditions at $25 \pm 2{ }^{\circ} \mathrm{C}$ and $65-70 \% \mathrm{RH}$ and under a photoperiod regime of 16:8 (light: darkness). The number of dead nymphs was cumulatively recorded daily. The final evaluation of the trial was carried out and the mortality rates were determined at $264 \mathrm{~h}$. Reisolation from the nymphs that were determined to be infected according to the Koch Postulates was performed and the entomopathogenic fungus and bacteria were recovered. The sterile water containing both the sterile NB medium used in the dilution of the bacteria solutions and $0.2 \mathrm{ml} / \mathrm{l}$ tween 80 solution used in the fungus suspensions was used as the negative control in the study. The trial was carried out in four repetitions for each combination in the same day.

\section{Potentials of some bacteria strains and the fungal isolate against the eggs of the pest}

After counting the eggs in the egg packs, the packs were removed from leaves and placed in Petri dishes, placed on blotting papers, to determine the effects of 11 bacterial strains and 1 fungal isolate (Table 1 ) on the eggs. The $\left(1 \times 10^{8} \mathrm{CFU} / \mathrm{ml}\right)$ bacteria and $\left(5.7 \times 10^{5}\right.$ conidia $\left./ \mathrm{ml}\right)$ fungal suspensions that were previously prepared for the nymph applications were sprayed onto the egg packs including 5-37 eggs. Sterile water was applied as a control application and the number of hatched eggs was counted.

\section{Statistical analysis}

The data obtained from different trials under controlled conditions were statistically analyzed, using the JMP 5.0 program. The differences among the applications were determined according to ANOVA results and "LSMeans Differences Student's" multiple comparison test.

\section{Results and discussion}

The effects of a total of 11 bacteria strains comprising: 6 Bacillus, 2 Pantoea, 1 Brevibacillus, 1 Pseudomonas, and 1 Vibrio and 1 fungal isolate on the nymphs of $H$. halys, the invasive pest, were tested and the results showed that all applications yielded different results than the control group and resulted in mortality rates between 75 and $100 \%$.

The bacterial strains yielded relatively more significant results as they were $5.0-40.0 \%$ after $24 \mathrm{~h}, 10.0-65.0 \%$ after 48 h, 29.2-76.7\% after 72 h, 37.5-76.7\% after 96 h, $37.5-85.8 \%$ after $120 \mathrm{~h}, 41.7-90.0 \%$ after $144 \mathrm{~h}, 41.7-$ 95.0\% after 168 h, 50.0-95.0\% after 192 h, 55.0-95.0\% after 216 h, $62.5-95.0 \%$ after $240 \mathrm{~h}$, and $75.0-100 \%$ after 264 h (Fig. 1).

According to the percentage mortality of nymphs, the difference between applications was found to be statistically significant $(F 13.59 ; p<0.01)$. The mean values of the mortality rates of the nymphs and hatched eggs to each of the entomopathogen bacterial strains and fungal isolate showed that the highest nymphal mortality rates (\%) were obtained by the FD 63 and FD 68 strains (100\%) (Table 2 ). The lowest mortality rate was obtained by the sterile water and NB medium-sprayed applications. Hyphal growths from $72 \mathrm{~h}$ showed the status of the nymphs (third and fourth nymphal instars) after 264 $\mathrm{h}$ from the applications of the bacteria and fungus that yielded the best results (Fig. 2).

The effects of the applications on egg hatching were investigated in the study. The control eggs and the eggs to which the ET 10 fungal isolate of B. bassiana and the FD 51 and FD 16 bacterial strains of $B$. thuringiensis kurstaki were applied, hatched in $96 \mathrm{~h}$, while hatching did not occur in B. cereus (FD 63, FDP 8), P. agglomerans (FD 68, FD 69), B. brevis (FD 1), P. flourescens (FD 71), B. atropheus (FD 17), V. hollisae (FD 70), and B. sphaericus (FD 49), even $264 \mathrm{~h}$ (Table 2). Figure 3 illustrates the pictures of the unhatched eggs and hatched eggs in the applications.

Although there are various studies on the use of bacteria and fungus in the biological control of pests, limited numbers of studies were found on the microbiological control of $H$. halys, comprising the studies of Gouli et al. (2011) and Kumar and Suktana (2017).

$B$. bassiana has a wide host range of hosts including hemipteran species (Gouli et al., 2011). Due to its environmentally friendly nature, bio-persistence and ability to kill pests at various developmental stages in their life cycle, the use of $B$. bassiana in Integrated Pest Management (IPM) programs is of great importance (Kumar and Suktana, 2017). The spores of $B$. bassiana attach to the insect's cuticle, they germinate, the hyphae penetrate the insect's body, and proliferate. The insects die after about 3-5 days and infected 

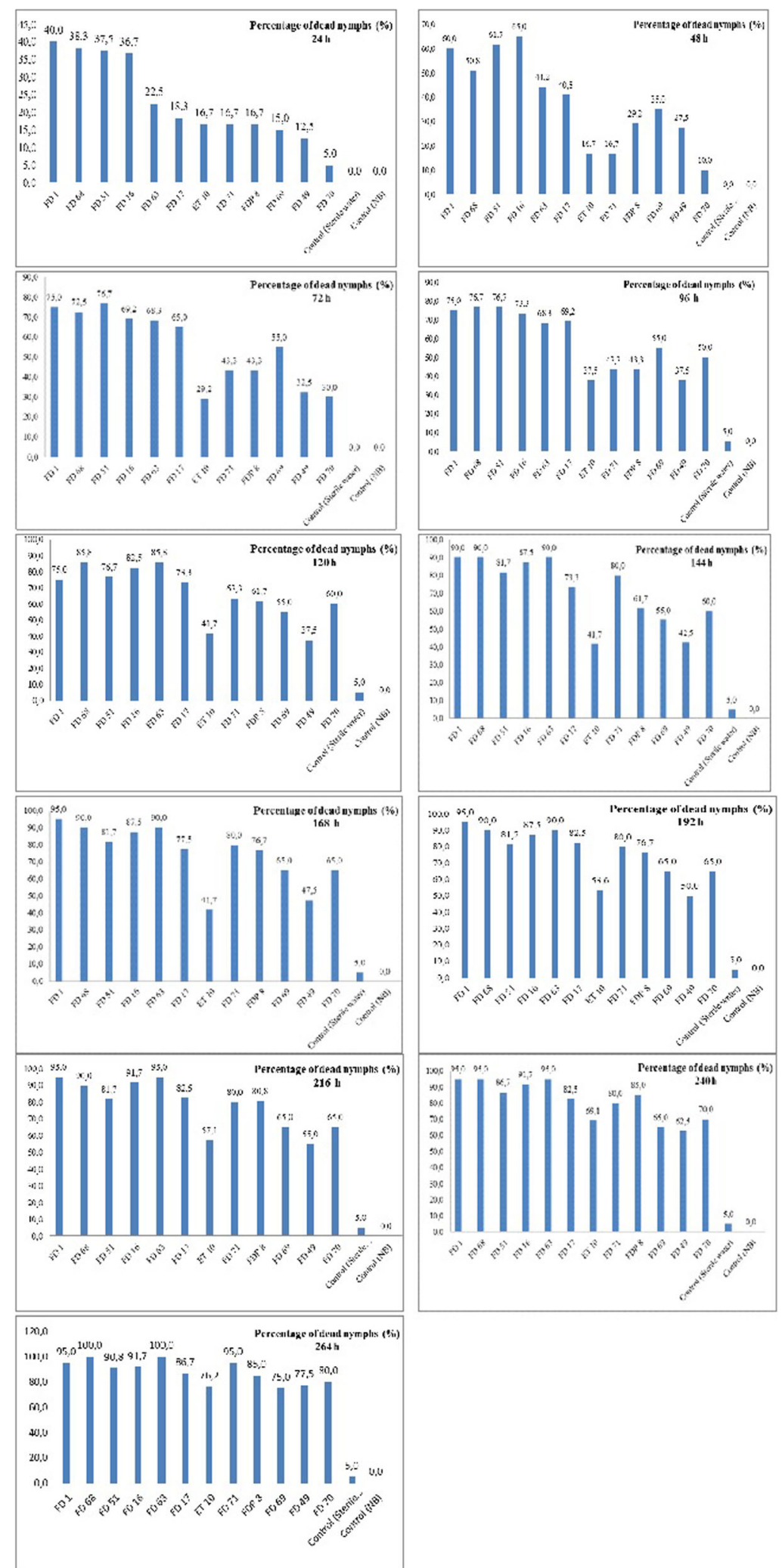

Fig. 1 Percentages of mortality of Halyomorpha halys nymphs in response to some entomopathogenic bacterial strains and fungal isolates by hours 
Table 2 Efficacy of some entomopathogen bacterial strains and fungal isolate on nymphs of Halyomorpha halys under controlled conditions after $264 \mathrm{~h}$

\begin{tabular}{|c|c|c|c|c|}
\hline \multirow{2}{*}{$\begin{array}{l}\text { Treatment } \\
\text { FD } 63 \text { (Bacillus cereus) }\end{array}$} & \multicolumn{2}{|c|}{ Death nymph ratio (\%) } & \multirow{2}{*}{$\begin{array}{l}\text { Number of eggs in packs (number) } \\
19\end{array}$} & \multirow{2}{*}{$\frac{\text { Number of hatched eggs }}{0}$} \\
\hline & 100.00 & A & & \\
\hline FD 68 (Pantoea agglomerans) & 100.00 & A & 37 & 0 \\
\hline FD 1 (Brevibacillus brevis) & 95.00 & $A B$ & 14 & 0 \\
\hline FD 71 (Pseudomonas flourescens) & 95.00 & $A B$ & 12 & 0 \\
\hline FD 16 (Bacillus thuringiensis kurstaki) & 91.67 & $A B$ & 28 & 28 \\
\hline FD 51 (Bacillus thuringiensis kurstaki) & 90.83 & $A B$ & 5 & 5 \\
\hline FD 17 (Bacillus atrophaeus) & 86.67 & $A B$ & 11 & 0 \\
\hline FDP 8 (Bacillus cereus) & 85.00 & $A B$ & 13 & 0 \\
\hline FD 70 (Vibrio hollisae) & 80.00 & $A B$ & 14 & 0 \\
\hline FD 49 (Bacillus sphaericus) & 77.50 & B & 26 & 0 \\
\hline ET 10 (Beauveria bassiana) & 76.19 & B & 8 & 8 \\
\hline FD 69 (Pantoea agglomerans) & 75.00 & B & 17 & 0 \\
\hline Control (Sterile water) & 5.00 & C & 10 & 10 \\
\hline Control (NB) & 0.00 & $C$ & 12 & 12 \\
\hline CV & \multicolumn{2}{|c|}{23.01} & & \\
\hline LSD & \multicolumn{2}{|c|}{24.87} & & \\
\hline
\end{tabular}

cadavers may serve as a source of spores for secondary spread of the fungus.

The first study on the use of entomopathogen fungus for the control of this pest was carried out in 2011 (Gouli et al. 2011). The efficacy of 2 Metarhizium anisopliae isolates and commercial preparations of $B$. bassiana isolates were investigated for the control of the pest. The researchers reported that using $M$. anisopliae achieved mortality rates ranged between 40 and $88 \%$ in adults $H$. halys, while it ranged between 67 and 100\%, 12 days after the application of $B$. bassiana, under controlled conditions. Other researchers applied commercial preparations of 2 different formulations of $B$. bassiana concentrations $\left(5 \times 10^{6}\right.$ and $1 \times 10^{7}$ conidia $\left.\mathrm{ml}^{-1}\right)$ under controlled conditions and found that the best results were obtained by using the concentration $\left(1 \times 10^{7}\right.$ conidia $\mathrm{ml}^{-1}$ ) as a wettable powder formulation. Mortality rates ranged between 78 and $100 \%$ after 12 days of application (Parker et al. 2015). In this study, mortality rates of $76.19 \%$ in the application of B. bassiana were also achieved after $264 \mathrm{~h}$, which agree with the results obtained in the previous study. Furthermore, ET 10 isolate (B. bassiana) was tested against Syrista parreysii larvae. The number of dead larvae and mortality rate (\%) of $10^{6}$, $10^{7}$, and $10^{8}$ conidial suspensions of ET 10 were 7.44 , $7.56,8.11$, and $82.72 \%, 83.95 \%$, and $90.12 \%$, respectively (Tozlu et al. 2017).

Erper et al. (2016) applied 2 Simplicillium lamellicola, 4 Lecanicillium muscarium, and $1 \mathrm{~B}$. bassiana and Isaria fumosorosea isolates under laboratory conditions at 25 ${ }^{\circ} \mathrm{C}$ to control the nymphs of Palonema prasina, a pentatomid species. They found that the $\mathrm{LT}_{50}$ values were between 3.20 and 8.48 days, while the $\mathrm{LT}_{90}$ values were between 9.32 and 40.30 days on day 12 of the study. In addition, they reported that all isolates, used in the study had efficacies over $83 \%$ and the highest percentage mortality (98 and 95\%) were obtained by $L$. musacarium and B. bassiana, respectively.

Various studies have reported that the most important bacterial species that yielded successful results in the biological control of pests were Bacillus varieties (Alper et al. 2013). B. thuringiensis was reported to be successful in controlling different pests' species (Helicoverpa armigera, Spodoptera litura, Pieris brassicae, and Spilarctia oblique) (Mohan et al. 2014).

A review of the scientific literature revealed no studies testing the efficacy of entomopathogen bacteria against $H$. halys, but the effects of the bacterial strains used in this study to test their efficacy against $H$. halys were determined for different pests in previous studies. In the present study, the efficacy of two B. cereus strains (FD 63 (36.6\%), FDP $8(76.6 \%)$ ), one B. atrophaeus strain (FD $17(36.6 \%)$ ) and one B. brevis strain (FD 1 (23.0\%)) against Bruchus dentipes under controlled conditions were investigated. The strains were reported to control the pests in 7 days (Tozlu et al. 2011). Dadaşoğlu et al. (2016) tested the efficacies of two strains of B. thuringiensis kurstaki (F 16, F51) and one strain of B. sphaericus GC subgroup ( F 49) against Diplion pini where the mortality rates ranged between 66.7 and $80 \%$, respectively, under controlled conditions. The results of the present study, also showed that B. cereus (FD 63, 


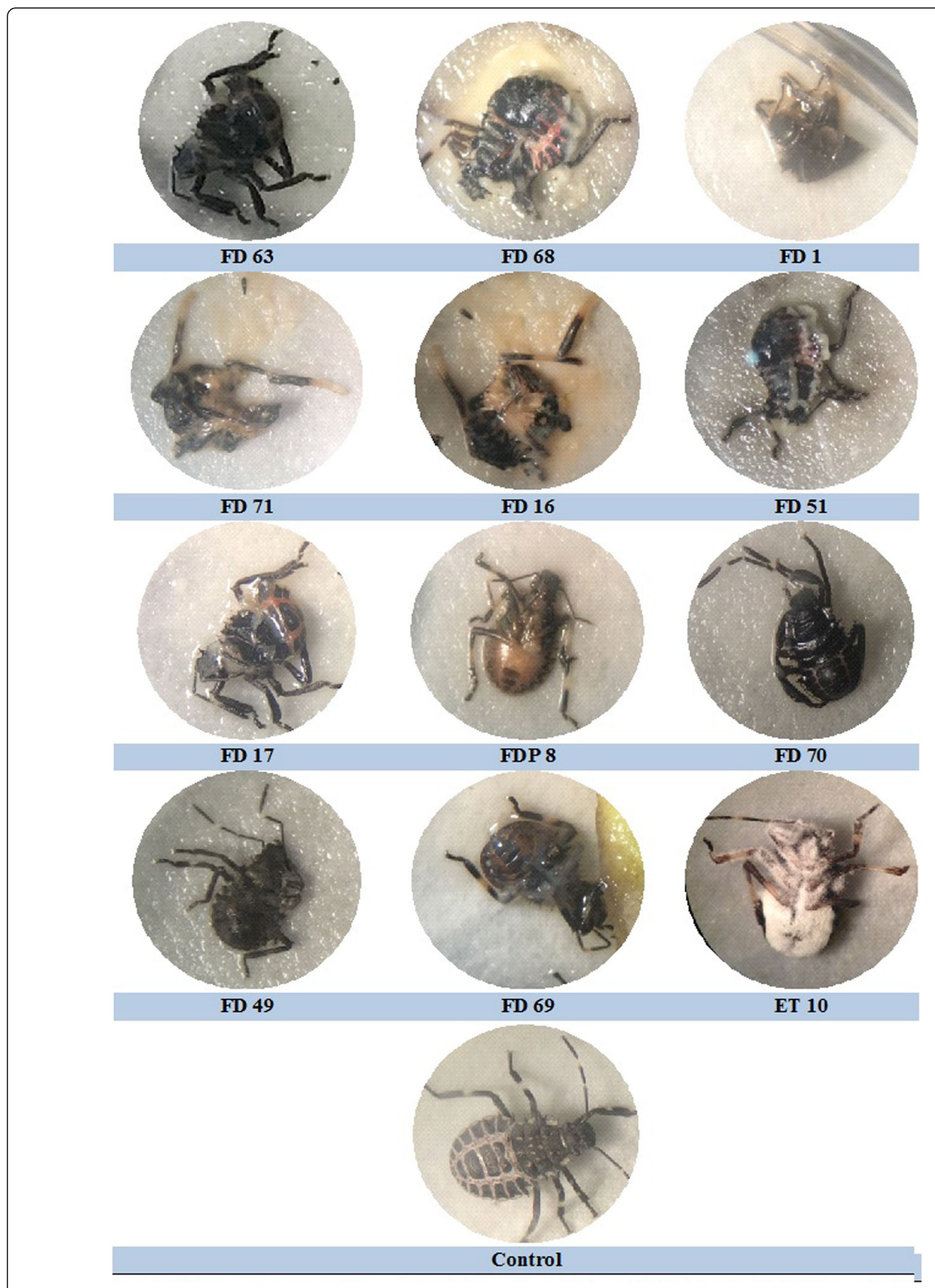

Fig. 2 Effects of the applications of bacterial strains and fungal isolate on the Halyomorpha halys nymphs after 264h 


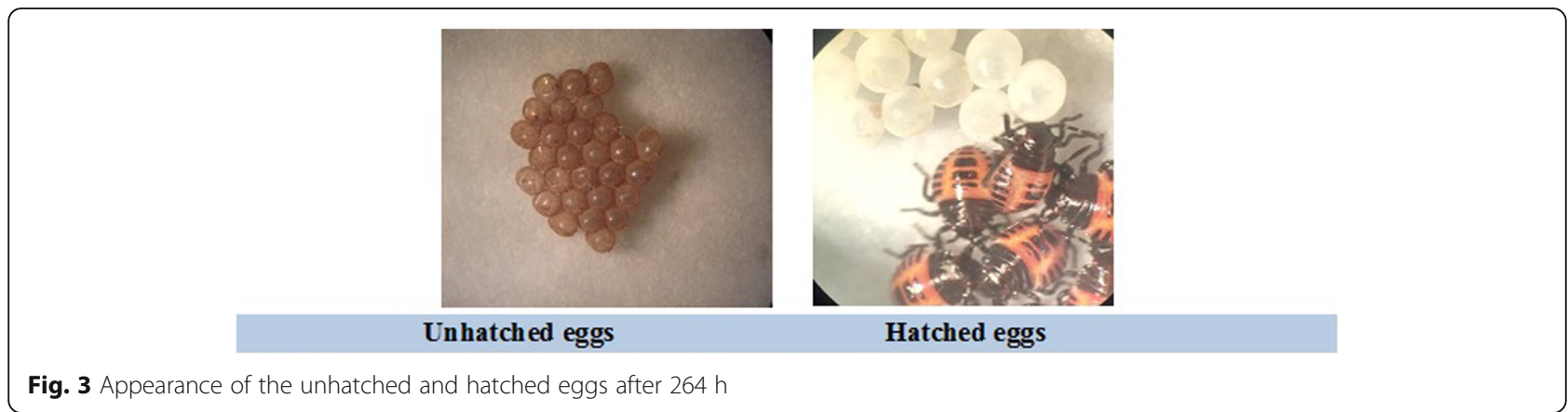

100.00\%), B. thuringiensis kurstaki (FD 16 (91.67\%), FD 51 (90.83\%)), B. atrophaeus (FD 17, 86.67\%), B. cereus (FDP 8, 85.00\%), B. sphaericus (FD 49, 77.50\%), and $B$. brevis (FD 1, 95.00\%) strains were effective against $H$. halys nymphs.

In addition, the pathogenicity of the two P. agglomerans strains (FD 69 (75\%) FD $68(100 \%)$ ) and one $V$. hollisae strain (FD 70, $80 \%$ ) against the nymphs of $H$. halys were successfully exterminated in this study. The eggs hatched in fungal isolate, B. thuringiensis kurstakii strains applications and control, although the eggs unhatched in other applications.

\section{Conclusion}

The study highlighted a successful usage of the environment-friendly control tool, the entomopathogens, against $H$. halys as a substitution of the chemical pesticides. Such potentials may be varied under field conditions. Therefore, the efficacy of the entomopathogens under field conditions against the different developmental stages of the pest should be tested.

\section{Acknowledgements}

Not applicable

\section{Authors' contributions}

$E T, I S, G T$, and RK conceived and designed research. IS collected $H$. halys nymphs from Artvin, Turkey. ET, GT, and RK conducted experiments. ET studied fungal experiments. RK and FD studied bacterial experiments. ET, GT, and NT studied controlled assay. ET analyzed the data. ET, GT, and RK wrote the manuscript. NT took photos of the study. All authors read and approved the final manuscript.

\section{Funding}

No funding

\section{Availability of data and materials}

The datasets used and/or analyzed during the current study are available from the corresponding author on reasonable request.

\section{Ethics approval and consent to participate}

Not applicable

\section{Consent for publication}

Not applicable

\section{Competing interests}

The authors declare that they have no competing interests.

\section{Author details}

${ }^{1}$ Faculty of Agriculture, Department of Plant Protection, Atatürk University, 25240 Erzurum, Turkey. ${ }^{2}$ Faculty of Agriculture, Department of Plant Protection, Ondokuz Mayıs University, 55139 Samsun, Turkey.

Received: 11 July 2019 Accepted: 9 October 2019

Published online: 25 November 2019

\section{References}

Alper M, Günes H, Civelek HS, Dursun O, Eskin A (2013) An investigation on the toxic effect of native Bacillus thuringiensis Berliner (Bacillales: Bacillaceae) isolates against Tetranychus urticae Koch (Acarina: Tetranychidae), Ceroplastes rusci L. (Homoptera: Coccidae) and Ceratitis capitata (Wiedemann) (Diptera: Tephritidae). Türk Entomol Bült 3(2):75-87 (in Turkish)

Bariselli M, Bugiani R, Maistrello L (2016) Distribution and damage caused by Halyomorpha halys in Italy. Bulletin OEPP/EPPO Bulletin 46(2):332-334

Bernon G (2004) Biology of Halyomorpha halys, the Brown Marmorated Stink Bug (BMSB). Final Report-USDA APHIS CPHST, p 17

Bhattarai SS, Koirala Bishwokarma S, Gurung S, Dhami P, Bishwokarma Y (2016) Efficacy of entomopathogens for control of blue pumpkin beetle (Aulacophora nigripennis Motschulsky, 1857) in sponge gourd (Luffa cylindrica) under laboratory condition at Paklihawa, Nepal. GJBAHS 5(2): 102-105

Çerçi B, Koçak Ö (2017) Further contribution to the Heteroptera (Hemiptera) fauna of Turkey with a new synonymy. Acta Biologica Turcica 30(4):121-127

Dadaşoğlu F, Tozlu G, Kotan R, Göktürk T, Karagöz K (2016) Biological control of Pine Sawfly (Diprion pini L.) and molecular characterisation of effective strains. Rom Biotech Lett 21(2):11272-11180

Erper I, Saruhan I, Akca I, Aksoy HM, Tuncer C (2016) Evaluation of some entomopathogenic fungi for controlling the green shield bug, Palomena prasina L. (Heteroptera: Pentatomidae). Egyptian J Biol Pest Control 26(3): $573-578$

Göktürk T, Tozlu G (2019) The effect of Pyrethrum and Bacillus thuringiensis biopesticides on Diprion pini L. and Neodiprion sertifer (Geoffr.) (Hymenoptera: Diprionidae). Larvae Pak J Zool 51(3):989-994

Gouli V, Gouli S, Skinner M, Hamilton G, Kim JS, Parker BL (2011) Virulence of select entomopathogenic fungi to the brown marmorated stink bug, Halyomorpha halys (Stål) (Heteroptera: Pentatomidae). Pest Manag Sci 68: 155-157

Haye T, Gariepy T, Hoelmer K, Rossi JP, Streito JC, Tassus X, Desneux N (2015) Range expansion of the invasive brown marmorated stinkbug, Halyomorpha halys: an increasing threat to field, fruit and vegetable crops worldwide. J Pest Sci 88:665-673

Hoebeke ER, Carter ME (2003) Halyomorpha halys (Stål) (Heteroptera: Pentatomidae): a polyphagous plant pest from Asia newly detected in North America. Proc Entomol Soc Wash 105:225-237

Klement Z, Rudolph K, Sands D (1964) Hypersensitive reaction induced by phytopathogenic bacteria in the tobacco leaf. Methods Phytobacteriol Phytopathol 54:474-477

Kuhar TP, Kamminga KL, Whalen J, Dively GP, Brust G, Hooks CRR, Hamilton G, Herbert DA (2012) The pest potential of brown marmorated stink bug on vegetable crops. Plant Health Progress 1-3.

Kumar S, Sultana R (2017) Effect of entomopathogenic fungi on the food consumption of Acrididae Species. World Acad Sci Eng Technol Int J Biol Biomolecular Agric Food Biotechnol Eng 11(6):360-364 
Mohan M, Rangeshwaran R, Sivakumar G, Verghese A (2014) Relative toxicity of subspecies of Bacillus thuringiensis against lepidopterous insect pests of agricultural importance. J Biol Control 28(4):197-203

Paisley R (1995) MIS whole cell fatty acid analysis by gas chromatography. MIDI, Inc, Newark, DE, p 5

Parker BL, Skinner M, Gouli S, Gouli V, Kim JS (2015) Virulence of BotaniGard ${ }^{\oplus}$ to Second Instar Brown Marmorated Stink Bug, Halyomorpha halys (Stål) (Heteroptera: Pentatomidae). Insects 6:319-324

Quesada-Moraga E, Landa BB, Muñozledesma J, Jıménez-Díaz R, Santıago Álvarez C (2006) Endophytic colonization of opium poppy, Papaver somniferum, by an entomopathogenic Beauveria bassiana strain. Mycopathol 161:323-329

Rice KB, Bergh CJ, Bergmann EJ, Biddinger D, Dieckhoff C, Dively G, Fraser HM, Gariepy TD, Hamilton G, Haye T (2014) Biology, ecology, and management of brown marmorated stink bug (Hemiptera: Pentatomidae). J Integr Pest Manag 5:A1-13

Rider DA (2006) Family Pentatomidae Leach, 1815. In: Aukema B, Rieger C (eds) Catalogue of the Heteroptera of the Palaearctic Region in Vol. 5. II. The Netherlands Entomological Society, Wageningen, pp 233-402

Tozlu E, Dadaşoğlu F, Kotan R, Tozlu G (2011) Insectıcıdal effect of some bacterıa on Bruchus dentipes Baudi (Coleoptera: Bruchidae). Fresenius Environ Bull 20(4):918-923

Tozlu E, Kotan R, Tozlu G (2017) The investigation of Beauveria bassiana (Ascomycota: Hypocreales) as a biocontrol agent of rose-stem sawfly, Syrista parreyssii (Spinola, 1843) (Hymenoptera: Symphyta; Cephidae) larvae. Fresenius Environ Bull 26(12):7091-7100

\section{Publisher's Note}

Springer Nature remains neutral with regard to jurisdictional claims in published maps and institutional affiliations.

\section{Submit your manuscript to a SpringerOpen ${ }^{\circ}$ journal and benefit from:}

- Convenient online submission

- Rigorous peer review

- Open access: articles freely available online

- High visibility within the field

- Retaining the copyright to your article

Submit your next manuscript at $\boldsymbol{\nabla}$ springeropen.com 